\title{
Experiences Flipping an Undergraduate Advertising Course
}

\author{
Robert Mark Rouwenhorst ${ }^{1}$ \\ ${ }^{1}$ Marketing Department, St. Ambrose University, Davenport, USA \\ Correspondence: Robert Mark Rouwenhorst, Assistant Professor, Marketing Department, St. Ambrose University, \\ Davenport, Iowa, USA. E-mail: rouwenhorstrobertm@sau.edu \\ Received: May 25, 2017 \\ Accepted: June 12, 2017 \\ Online Published: July 9, 2017 \\ doi:10.5430/ijba.v8n5p1 \\ URL: https://doi.org/10.5430/ijba.v8n5p1
}

\begin{abstract}
This article discusses the positive outcomes of changing to a flipped classroom instructional approach and how creating a greater sense of influence and control for students in group projects can positively impact multiple measures of student performance and self-reported attitudes. Two sections completed the same readings and videos covering 13 course content modules. Rather than a traditional lecture-based course, most of the class time was used on experiential learning activities. Students worked with real-world clients to create advertising campaigns. One section completed research and pitched their ideas for a social media campaign to a franchise with over 50 restaurants. This section was seen as "low ownership" because students did not know if their ideas would be implemented. The second section created an integrated marketing campaign for an event on campus that drew over 400 attendees. This section is labelled as "high ownership" because the students felt more involved with their project as they imagined, created, and executed the advertising and organization for an event. Overall, most students in both sections preferred the flipped approach to traditional lecture. While the percent of videos watched and grades did not differ between the two sections, students in the high ownership section reported more interest in their project, were more likely to recommend keeping the flipped approach, were more likely to recommend the course to others, found the flipped classroom more interesting than lecture-only classes, and said they learned more using a flipped approach vs. a lecture-only class. These results demonstrate how flipped classrooms and experiential learning exercises with real-world results can improve marketing education.
\end{abstract}

Keywords: flipped classroom, blended learning environment, inverted classroom, experiential learning, advertising course

\section{Introduction}

Recent studies have shown that undergraduate students' scores on standardized measures of critical thinking and complex reasoning improve very little while they are in college (Arum \& Ruska, 2011, Pascarella et al., 2011). While methodological limitations can make interpretation of these findings challenging and controversial (Pascarella et al., 2011), less debatable are the interpretations of data on student engagement and time spent studying. For instance, Roska \& Arum (2011) found the typical undergraduate studied 12 hours a week during their sophomore year and that almost 40 percent of sophomores spent less than 5 hours a week studying independently. This is considerably less time spent studying than previous generations. On average, students in 1961 spent 40 hours per week in class or studying while students in 2003 spent 27 hours per week on the same activities (Babcock \& Marks, 2011). Unfortunately, business school students have some of the worst performance on these measures: scoring low in engagement and time spent studying as well as having some of the weakest gains in standardized test scores (Glenn, 2011).

Numerous solutions have been proposed for these problems. For instance, Peer Instruction, a technique that encourages students to discuss concepts with other students, can improve conceptual and quantitative skills as well as student engagement (Crouch \& Mazur 2001). Active learning techniques, which encourage students to interact with course content through talking, listening, writing and reflecting, have been shown to improve both understanding and course enjoyment (Meyers \& Jones, 1993; Camp 2000; Benek-Ricera \& Mathews, 2004). Other active learning activities, like using game-show questions for exam review, can motivate students to participate in class and assume more responsibility for their learning (Meyers \& Jones, 1993; Benek-Rivera \& Mathews, 2004); clickers have been shown to have similar positive results (Hedgcock \& Rouwenhorst, 2014). While Arum and Ruska (2011) reported a negative correlation between group study time and improvements in critical thinking, others have found that group learning can 
be effective if individuals are held accountable for their achievement (Slavin, 1983). Instructors can enhance student learning and satisfaction in group projects by creating a sense of ownership in the minds of the students (Wood, 2003).

"In relatively few instances in established business schools is there much clinical training or learning by doing experiential learning where concrete experiences is the basis for observation and reflection" (Pfeffer \& Fong, 2002, pg. 85). Experiential learning often encourages those involved to experience, reflect, think, and act (Kolb, 1984; Kolb, Boyatzis, \& Mainemelis, 2001). Because the pedagogy is such a drastic departure from traditional, lecture-based approaches, greater effort is required in curriculum development for a successful adoption of experiential learning (Daly, 2001). University faculty face challenges with innovation adoption, "which is characterized by unique applications that result in extending the classroom in ways that result in more current, active, and interactive learning environment" (Celsi \& Wolfinbarger, 2002, pg. 64).

This article looks at the benefits of adopting a flipped classroom approach where students watched videos outside of class time to gain the knowledge they would have received in a traditional, lecture-based course. The vast majority of class time was spent on experiential learning and having the students work on real-world projects for various clients. Two classes used the same materials, videos, instructor, etc. Their difference was the project used in the course that accounted for fifty percent of students' overall grades. One class, labelled "low ownership," proposed a social media campaign for their client without knowing if the campaign would win over other groups' ideas, let alone be made into a real campaign. The second class, labelled "high ownership," created marketing materials that were actually used and distributed by the students and client. The overall views of flipped classes and differences between the low/high ownership groups is discussed.

\section{Literature Review}

The lecture format has been traditional model of business education delivery (Kunkel \& Shafer, 1997). For effective learning to occur, students must be actively engaged in the learning process (DeLay, 1996). The success of experiential education stems from the fact it actively involves and empowers students through a "bottom-up" versus a "top-down" educational process (Margerison, 1988). Whitener (2001) showed that group members became more involved and committed to tasks within organizations when they trusted their leaders and perceived their leaders to be supportive and committed to those they led. Wood (2003) found that students reported learning more from experiential teaching methods versus traditional lecture-based methods.

Bloom (1956) stated that the focus of class time should be on applying, analyzing, and evaluating knowledge rather than on basic understanding. Roach, Johnston, and Hair (1993) found three major teaching styles that are based on a continuum of student involvement in their educational process: the "student passive" approach, reflecting an environment where the instructor adopts a one-way communication process; the "student communicator" approach, reflecting a group experience with the instructor as the one leading; and the "student interactive" approach, reflecting an environment where students make decisions and apply what they have learned. An interactive teaching style has been shown as the most important factor influencing course effectiveness and student learning (Conang, Smart, \& Kelly, 1988).

Research on active learning has shown that it contributes to student learning, achievement, and engagement (Chapland, 2009; Freeman et al., 2007; Knight \& Wood, 2005; Prince, 2004). King (1993) described two contrasting instructor roles as "sage on the stage" and "guide on the side." Historically, the role of the instructor has been to communicate knowledge to students during lecture. King (1993) viewed this as a passive approach to learning, called the transmittal model. In contrast, the "guide on the side" views the instructor as a facilitator by enabling students to actually do something with the information they have read and heard. Drea, Singh, and Engelland (1997) and McCormick (1993) concluded that experiential learning can enhance the relevance and value of classroom material through the application of said material.

Student learning and satisfaction in group projects can be augmented by creating a sense of ownership in the minds of the students (Wood, 2003). Buchko (1992) found that ownership affects students attitudes primarily through providing a greater sense of influence and control. Duray and Milligan (1999) stated that efforts to increase ownership in the product design and production process with customers improve satisfaction and relationships with those customers.

Collaborative assignments are considered a high-impact educational practice (LEAP Initiative, 2013), and their benefits have been well documented (see, Gaidis \& Andrews, 1990; Haas \& Wotruba, 1990; Scovotti, 2016). Hart Research Associates (2013) states that successful group projects help students become more employable. Their study found that 79 percent of business owners with more than 25 employees want students to complete a project that demonstrates their acquired knowledge and skills prior to graduation. High-impact learning practices can require 
students to devote considerable time outside of the classroom environment (NSSE, 2014). However, students lead very busy lives with responsibilities far beyond pure academic pursuits. Nonis and Hudson (2006) stated that students spend very little time studying and have difficulty finding convenient time to meet with their peers. The National Survey of Student Engagement (2014) reported that study time is especially lacking in seniors. Seniors with a 15-credit load studied an average of 14.8 hours per week. Additionally, seniors work on average 15 hours per week (NSSE, 2014).

Online learning is already very popular with students in higher education (Snowball, 2014). In higher education, flipped classrooms are emerging as one of the more recent pedagogical innovations (Steed, 2012). The flipped classroom pedagogy fits well with the demand for online learning. A flipped course redesigns the entire educational process, literally "flipping" the service delivery from entirely face-to-face contact to party virtual or "blended" contact (Garrison \& Kanuka, 2004). Flipping course content frees up time in the classroom for face-to-face contact and active student interaction by delivering lecture content online (Green, 2015). The learning difference in flipped courses is that when students arrive to class, it is not for traditional instruction but rather interactions with their class peers and instructors that take place embedded in a social learning environment. For this reason, flipped courses have been described as more social inclusive (Lage, Platt, \& Treglia, 2000).

The Association to Advance Collegiate Schools Business (AACSB), an international accreditation organization for business schools, has viewed technology as a context for business courses (AACSB, 2013). Alavi and Gallupe (2003) states that business schools are earnestly attempting to create better learning experiences by blending information technology with the classroom environment.

There is no single best model for a flipped classroom (Educause, 2012). While students engage more with course materials and their peers in a flipped class, instructors are challenged by the time commitment required to flip a course (Herried \& Schiller, 2013). In addition to creating videos, instructors must organize readings, quizzes, and other online activities on the course web site prior to the start of the semester (Scovatti, 2016).

Engaged students are known and more likely to stay at the university and continue their studies (Russell-Bennett et al., 2010). Research indicates that interactive student-centered activities and learning experiences enriches the learning process much more than can be achieved in a traditional lecture (Zappe et al., 2009). Russell-Bennett et al. (2010) found that when the learning environment is enriched with different types of educational experiences, students were more likely to engage with course content. For example, the authors found that having students develop their own market spaces proved useful in developing student-centered learning. Albert and Beatty (2014) found that compared to a lecture course, grades on exams were higher in a class using a flipped model. Put simply, when students are engaged with their course content, they are likely to learn more, achieve more, and subsequently do more with their educational studies (Green, 2015).

\section{Research Method}

All marketing majors at a small, private, Midwestern university have the option to take a three-semester-hour Advertising course as an elective. For several years, the instructor has used a major team project where the students consult with a local business and then pitch their ideas to this business similar to how real-life advertisers must pitch their ideas to clients. After learning about the benefits of flipped classrooms, the instructor decided to flip his Advertising classes beginning in the Fall 2015.

The learning objectives remained the same as they were in prior semesters. Students completed the same two individual assignments and one major team project that had been used previously. The main difference between the flipped class and traditional, lecture-based classes of the past were the instructor recorded videos for 13 modules of various class topics. The videos varied in length from 11-45 minutes with an average length of 32 minutes. These videos were substantially shorter compared to the time historically required to deliver the content as discussion between the instructor and students was eliminated. Short videos also enable students to quickly review specific content throughout the semester (Brecht \& Ogilby, 2008). All were edited on an Apple MacBook Pro using iMovie. The videos featured the instructor talking to the camera for the majority of the video. The instructor would talk based off the lecture notes which were provided to students. To allow students to follow along in the slide deck, the slide being discussed would be digitally superimposed onto on the screen for 4 seconds as the instructor continued to lecture. To help keep viewers' attention, other elements were edited onto the screen. For instance, if "Lay's potato chips" were mentioned, a picture of a bag of Lay's potato chips would zoom onto the screen to the side of the instructor's face. Additional videos would be inserted if they added value to the discussion. If a commercial was discussed in the lecture, that advertisement may have been shown during the video. 
All videos were uploaded to YouTube as unlisted videos, such that only persons with the unique URL could view the video. Based on the instructor's previous experience, YouTube was a much more reliable viewing platform than the university's learning management software in terms of performance on the students' home computers. In addition, the YouTube platform provided several benefits to the students and instructor. YouTube remembers where viewers leave a video or pause it and will pick up from this point should a viewer not complete a video in one sitting. Using the course management software, the instructor could track how many students clicked to watch a particular video. Using the analytics provided by YouTube, the instructor assessed how long the average person watched the videos and how many viewed them. However, the number of unique viewers is unable to be assessed, and persons that paused a video and returned to it later would lead to the statistics regarding length of views and total views on YouTube to be inaccurate. Therefore, the measure of most concern was how many students accessed the video through links embedded in the university's learning management software.

In addition to the videos being used as the main means of knowledge transfer, the instructor switched from using two exams to using a weekly quiz to help assess students' learning. The instructor had previously flipped a class and continued to use exams to judge student learning. However, this led to students viewing the videos immediately prior to the exams with resultant decreased knowledge retention. As such, when the Advertising class was flipped in Fall 2015, students' knowledge was assessed using a weekly quiz covering the week's video(s). At the beginning of the first class each week, students would take a quiz of two essay questions related to the content of the videos students were supposed to have watched prior to class. There were 14 quizzes in total, worth $25 \%$ of the students' final course grade.

The use of video to deliver content freed up time for group interaction and work on the team project. Fifty percent of the students' overall course grade was associated with the client's evaluation of the team project. Given the fact that real companies' dilemmas were used for team projects, the scope and deliverables varied each semester. With the nature of the projects for the two classes described below, we can look at differences between a project of low ownership and one of high ownership. Several studies described in the literature review (see Buchko, 1992; Duray \& Milligan, 1999; Wood, 2003), discuss how instructors can enhance student learning and satisfaction in group projects by creating a sense of ownership in the minds of the students. The project used in the first flipped Advertising course was deemed "low ownership" whereas the second class' project was "high ownership." Therefore, we can look at the differences in student attitudes toward flipped classes when the major project in the course varies in how students feel connected to their projects.

The impact of flipping the classroom was tested using several measures, including: (1) students' assessments of their own performance and knowledge, (2) objective assessments of performance including video click-thru rates and quiz scores, (3) students' self-reported attitudes toward flipped classes, the instructor, and the class. Anonymous surveys were administered during the last class of each section. The surveys were collected by one of the students, sealed in an envelope, and delivered to the department secretary. Survey responses were not reviewed until the semester was over and grades were submitted.

\subsection{The First Flipped Class - Low Ownership}

There were thirty-six students enrolled in the first advertising course that used a flipped approach. The course met for 75 minutes twice a week for 16 weeks. Outside of class, students were expected to watch videos prepared on that week's topic(s). The majority of the videos were made by the instructor, but additional videos such as two documentaries (Art \& Copy and The Naked Brand) and various videos from TED.com were also used.

The vast majority of class time was spent on a project for a real-world client. The students were broken up into eight teams of four to five students. The client for this course was the chief marketing officer of a popular pizza restaurant chain. This chain has over 50 franchises located mostly in the Midwest United States. The client was releasing a thin crust pizza and asked for two deliverables from students. The first deliverable was a research report containing secondary and primary data. Students were tasked with conducting research regarding the popularity of thin crust pizza in the United States. Then the students created, distributed, and analyzed survey data of local pizza customers to gauge their affinity for thin crust pizza. The second deliverable involved students pitching ideas for a social media marketing campaign for the new thin crust pizza.

\subsection{The Second Flipped Class - High Ownership}

The second flipped class took place the semester after the first flipped course. All videos, materials, grading, survey questions, etc. were the same as the first flipped course except for the client and project given to the students which once again accounted for $50 \%$ of their overall course grade. There were twenty-two students in this course and they 
were divided into teams of three to four students each. The project was to create the advertising, both print and digital, for a conference the College of Business was going to host at the end of the semester.

To help create the tangibles such as the conference name, tagline, logo, and more, the teams each pitched their ideas to various faculty judges throughout the semester. Once a winning idea/logo/etc. was selected, all teams would adopt this piece and use it in the next pitch. At the end of the semester, the class was in charge of hanging over 200 copies of a poster they had created, 500 door hangers in the dorms, two ads placed in the local newspaper, as well as all the messaging on various social media platforms including Facebook, Snapchat, Twitter, and Instagram.

Every project and client is going to vary, so they can be difficult to compare. However, the author can safely state that the second flipped course had more to do, more tangibles associated with their work, and a greater feeling of ownership than those in the first class.

\section{Results}

Self-reported measures were collected using anonymous surveys distributed during the last class. Students answered the questions on six-point Likert scales ( $1=$ "strongly disagree," $6=$ "strongly agree"). The number of videos each student watched was tracked through the course management system. Overall course grades were also kept and included in the analysis.

Students in the low ownership class watched on average $85.13 \%$ of the videos throughout the course. Those in the high ownership class watched $79.59 \%$ of the videos. The differences between the two classes was not significant, $p=0.38$. The overall grades between the two classes was not statistically significant either, $\bar{x}=83.33 \%$ vs. $\bar{x}=89.19 \%, t(56)=$ $-1.66, p=0.10$. However, there was a significant correlation between the number of videos watched and a student's overall grade in the course, $\mathrm{r}=0.47, p<0.01$.

\begin{tabular}{|c|c|c|c|c|c|c|}
\hline Question & $\begin{array}{c}\text { Strongly } \\
\text { Agree } \\
\end{array}$ & $\begin{array}{c}\text { Moderately } \\
\text { Agree }\end{array}$ & $\begin{array}{c}\text { Slightly } \\
\text { Agree }\end{array}$ & $\begin{array}{c}\text { Slightly } \\
\text { Disagree }\end{array}$ & $\begin{array}{c}\text { Moderately } \\
\text { Disagree }\end{array}$ & $\begin{array}{l}\text { Strongly } \\
\text { Disagree }\end{array}$ \\
\hline I found the videos in this class interesting. & $35 \%$ & $46 \%$ & $19 \%$ & $0 \%$ & $0 \%$ & $0 \%$ \\
\hline I have a good understanding of the material. & $22 \%$ & $54 \%$ & $24 \%$ & $0 \%$ & $0 \%$ & $0 \%$ \\
\hline I have been interested in the consulting project. & $62 \%$ & $30 \%$ & $8 \%$ & $0 \%$ & $0 \%$ & $0 \%$ \\
\hline I would recommend keeping the "flipped" format for this class. & $43 \%$ & $19 \%$ & $19 \%$ & $16 \%$ & $3 \%$ & $0 \%$ \\
\hline I would recommend a course taught by this instructor to other students. & $81 \%$ & $16 \%$ & $3 \%$ & $0 \%$ & $0 \%$ & $0 \%$ \\
\hline A flipped classroom is more interesting than lecture-only classes. & $46 \%$ & $30 \%$ & $8 \%$ & $14 \%$ & $3 \%$ & $0 \%$ \\
\hline I have learned more using the flipped classroom approach versus a lecture-only class & $32 \%$ & $41 \%$ & $5 \%$ & $16 \%$ & $5 \%$ & $0 \%$ \\
\hline The consulting project has improved my understanding of advertising. & $76 \%$ & $24 \%$ & $0 \%$ & $0 \%$ & $0 \%$ & $0 \%$ \\
\hline If I had my choice, more classes would use a "flipped classroom" approach. & $43 \%$ & $24 \%$ & $14 \%$ & $11 \%$ & $5 \%$ & $3 \%$ \\
\hline
\end{tabular}

As can be seen in Table 1, students in the low ownership had overwhelmingly positive attitudes toward the class, instructor, project, and the flipped classroom approach. Similarly, students in the high ownership class (see Table 2) also had positive views toward class, instructor, project, and the flipped classroom approach. However, it is worth pointing out that views toward the flipped classroom are not universally positive. Students that have thrived in a traditional, lecture-based course may be resistant to change. As more time is focused on the group projects and more weight on students' grades is placed on the team projects, instructors need to be even more cognizant of problems occurring between team members and have system in place to address non-contributory students, uncommunicative partners, etc. 
Table 2. Second Class' (High Ownership) Attitudes Toward Flipped Class at End of Semester

\begin{tabular}{|c|c|c|c|c|c|c|}
\hline Question & $\begin{array}{c}\text { Strongly } \\
\text { Agree }\end{array}$ & $\begin{array}{c}\text { Moderately } \\
\text { Agree }\end{array}$ & $\begin{array}{c}\text { Slightly } \\
\text { Agree }\end{array}$ & $\begin{array}{l}\text { Slightly } \\
\text { Disagree }\end{array}$ & $\begin{array}{c}\text { Moderately } \\
\text { Disagree }\end{array}$ & $\begin{array}{l}\text { Strongly } \\
\text { Disagree }\end{array}$ \\
\hline I found the videos in this class interesting. & $22 \%$ & $43 \%$ & $17 \%$ & $13 \%$ & $4 \%$ & $0 \%$ \\
\hline I have a good understanding of the material. & $39 \%$ & $43 \%$ & $13 \%$ & $0 \%$ & $4 \%$ & $0 \%$ \\
\hline I have been interested in the consulting project. & $91 \%$ & $9 \%$ & $0 \%$ & $0 \%$ & $0 \%$ & $0 \%$ \\
\hline I would recommend keeping the "flipped" format for this class. & $78 \%$ & $13 \%$ & $9 \%$ & $0 \%$ & $0 \%$ & $0 \%$ \\
\hline I would recommend a course taught by this instructor to other students. & $100 \%$ & $0 \%$ & $0 \%$ & $0 \%$ & $0 \%$ & $0 \%$ \\
\hline A flipped classroom is more interesting than lecture-only classes. & $74 \%$ & $22 \%$ & $4 \%$ & $0 \%$ & $0 \%$ & $0 \%$ \\
\hline I have learned more using the flipped classroom approach versus a lecture-only class & $74 \%$ & $13 \%$ & $4 \%$ & $9 \%$ & $0 \%$ & $0 \%$ \\
\hline The consulting project has improved my understanding of advertising. & $83 \%$ & $13 \%$ & $0 \%$ & $4 \%$ & $0 \%$ & $0 \%$ \\
\hline If I had my choice, more classes would use a "flipped classroom" approach. & $61 \%$ & $26 \%$ & $9 \%$ & $0 \%$ & $4 \%$ & $0 \%$ \\
\hline
\end{tabular}

The attitudes of students in the high ownership condition are reported in Table 2. Again, students had very positive attitudes toward the class, project, instructor, and flipped classrooms versus traditional, lecture-based methods of delivery. Students in the high ownership condition had significantly more interest in their project as indicated by their responses to, "I have been interested in the consulting project," 5.91 vs. 5.53 in the low ownership condition, $t=2.57$, $p<0.01$. Although intense effort was required from students, those in the high-ownership condition could see the tangible results of their efforts. The conference they helped advertise had over 400 attendees. There were 2,087 website visitors, 969 Facebook impressions, and ads that ran in the local newspaper, whose daily distribution varies from $51,000-68,000$ readers. All of these promotions were created by the students themselves.

Table 3. Self-Reported Attitudes at End of Semester

\begin{tabular}{|c|c|c|c|c|}
\hline Question & $\begin{array}{l}\text { First Class ( } \mathrm{n}=36) \\
\text { Low Ownership } \\
\text { Mean (S.D.) }\end{array}$ & $\begin{array}{c}\text { Second Class }(n=22) \\
\text { High Ownership } \\
\text { Mean (S.D.) }\end{array}$ & $t$-value & $p$-value \\
\hline I found the videos in this class interesting. & $5.14(0.52)$ & $4.64(1.29)$ & -2.06 & $0.04 *$ \\
\hline I have a good understanding of the material. & $4.94(0.45)$ & $5.09(0.94)$ & 0.68 & 0.5 \\
\hline I have been interested in the consulting project. & $5.53(0.43)$ & $5.91(0.09)$ & 2.57 & $0.01 * *$ \\
\hline I would recommend keeping the "flipped" format for this class. & $4.81(1.53)$ & $5.68(0.41)$ & 3.07 & $0.003 * *$ \\
\hline I would recommend a course taught by this instructor to other students. & $5.78(0.23)$ & $6.00(0)$ & 2.14 & $0.04 *$ \\
\hline A flipped classroom is more interesting than lecture-only classes. & $5.00(1.37)$ & $5.68(0.32)$ & 2.55 & $0.01 * *$ \\
\hline I have learned more using the flipped classroom approach versus a lecture-only class. & $4.75(1.51)$ & $5.50(0.93)$ & 2.44 & $0.02 *$ \\
\hline The consulting project has improved my understanding of advertising. & $5.75(0.19)$ & $5.72(0.49)$ & -0.15 & 0.88 \\
\hline If I had my choice, more classes would use a "flipped classroom" approach. & $4.81(1.99)$ & $5.36(1.00)$ & 1.62 & 0.11 \\
\hline
\end{tabular}

Note: ${ }^{*} p<0.05 ; * * p<0.01$ (two-tailed tests)

Table 3 compares the students' responses to their overall perceptions of the class between the two classes. Students who were in the high ownership class were significantly more likely to: (1) have more interest in the consulting project; (2) recommend keeping the "flipped" format for the class; (3) recommend a course taught by the instructor to other students; (4) believe a flipped classroom to be more interesting than a lecture-only class; and (5) believe they learned more using a flipped classroom approach versus a lecture-only class. The only other significant difference between the two sections was those in the low ownership course reporting finding the videos more interesting that those in the high ownership group. As the high ownership group reported their interest in the consulting project as 5.91 on a 6.00 scale, there may have been a slight tradeoff in having students so interested in the group project that they were less interested in watching pre-recorded lecture content.

\section{Discussion and Recommendations}

Two Advertising courses used a flipped classroom approach where course content was communicated to students using videos which they were to watch outside of class. Each week, a quiz was given in class to assess student learning from the videos to be viewed that week. Additionally, the course learning management system tracked which students watched the videos and which did not. All individual assignments, instructor, and points distributions were identical between the two courses. What varied between the two courses were the clients and deliverables of the group projects. Each class was broken up into small teams of three to five students per team. One course conducted market research and pitched their ideas for a social media campaign for a pizza franchise with over 50 franchises. This class was regarded as the "low ownership" condition because the students did not know if their ideas were going to selected as 
the winning campaign, let alone actually executed by the client. Conversely, the second class worked on creating the name, tagline, and all adverting for a conference the university's College of Business was hosting that semester. The students in this course helped raise over $\$ 5,000$ in funding and \$2,500 in free advertising. The conference had over 400 attendees. There were 2,087 website visitors, 969 Facebook impressions, and ads that ran in the local newspaper, whose daily distribution varies from 51,000-68,000 readers. The students in this "high ownership" class felt more connected to their project as they planned and executed it.

Students who were high ownership where they saw the outcomes of their work had significantly higher attitudes than students in the low ownership condition in five ways: (1) Had more interest in the consulting project; (2) Recommended keeping the "flipped" format for this class more; (3) Recommended a course taught by this instructor to other students more; (4) Believed a flipped classroom is more interesting than a lecture-only class; and (5) Believed they learned more using a flipped classroom approach versus a lecture-only class. While not universal, students in both conditions had very favorable views of the flipped classroom approach, and both classes recommended the continued use of the flipped class approach.

Passion is crucial to the success of flipped courses because the more novel the experience, the more potential there is for people to resist change (Waddell \& Sohal, 1998). Oreg (2003) found that people can resist change due to a reluctance to lose control, a lack of psychological resilience, cognitive rigidity, intolerance of the adjustment period required for change, have preference for low stimulation and novelty, and a reluctance to give up old habits. Therefore, passionate instructors who are keen to implement pedagogical change with flipped classrooms is a requirement for success (Ford, Ford, \& D’Amelio, 2008).

When lecture content is prerecorded, there are additional issues for instructors to consider besides those normally encountered in face-to-face education. This includes practical issues such as the need for no background or "white" noise during recording, the need for special lights and a well-lit room, and to consider whether students see instructors and lecture slides on screen simultaneously (Green, 2015). While it certainly is not easy to alter the habit of being the "sage on stage" into being a "guide on the side," it is worthwhile based on student feedback. The results reported above demonstrate how flipped classrooms and experiential learning exercises with real-world results can improve marketing education.

\section{Limitations and Future Directions}

Mediation analysis would provide a more complete picture about how the self-reported measures affected overall grades. However, it was not possible here as the students' overall grades could not be linked to their anonymous, self-reported measures. Benefits from anonymity (e.g., increased honesty in answering questions, decreased privacy concerns) likely offset the drawbacks inherent to the lack of a mediation analysis, but future studies could be designed to address this limitation.

Although the flipped classroom approach has been used for years, the approach is still relatively new to many instructors and students. Of the 58 students in the two classes reported, only six students had experienced a flipped class before. While several courses at this university use a flipped approach, the courses discussed were the only ones using a flipped approach in the marketing department. This means there was a potential for novelty effects, which could inflate some of the study's measures and make flipped classes seem more effective than they normally would be. Alternatively, this newness may have hurt the measures since the instructor had little experience with producing videos and flipping classes, and students may have been nervous about using a different style of learning. In addition, the research focused on the impact of flipped classes on students but did not investigate the impact of changing to a flipped classroom on the instructor. Future research could address these issues by examining how past experience with flipped classrooms alters their effectiveness and by examining how instructors are impacted by flipping their classes.

Future studies may also address the best practice for how to convey material outside of the classroom. Although videos of the instructor lecturing to the camera were used in both the courses discussed, alternative - and perhaps better delivery methods are possible. For instance, auditory learners may excel with podcasts. If visual learners do better with videos, comparisons should be made between voiced-over slides with videos of a professor's in-class lecture versus a highly edited video of the professor lecturing (as was done in this study). Answering questions like these will further our understanding of how to deliver the best learning environment for a variety of students and their unique learning styles as instructors continue to pursue online and flipped courses. 


\section{References}

Abeysekera, L., \& Dawson, P. (2015). Motivation and Cognitive Load in the Flipped Classroom: Definition, Rationale and a Call for Research. Higher Education Research \& Development, 34(1). https://doi.org/10.1080/07294360.2014.934336

Alavi, M., \& Gallupe, R. (2003). Using Information Technology in Learning: Case Studies in Business and Management Education Programs, Academy of Management Learning and Education, 2, 139-153. https://doi.org/10.5465/AMLE.2003.9901667

Albert, M., \& Beatty, B. (2014). Flipping the Classroom Applications to Curriculum Redesign for an Introduction to Management Course: Impact on Grades. Journal of Education for Business, 89(8). https://doi.org/10.1080/08832323.2014.929559

Arum, R., \& Roksa, J. (2011). Academically Adrift: Limited Learning on College Campuses. Chicago, IL: University of Chicago Press.

Association to Advance of Collegiate Schools of Business (AACSB). (2013). Learning and Teaching Standards. Retrieved from http://www.aacsb.edu/accreditation/standards/2013-business/learning-and-teaching/

Babcock, P., \& Marks, M. (2011). The Falling Time Cost of College: Evidence from Half a Century of Time Use Data. The Review of Economics and Statistics, 93(2), 468-478. https://doi.org/10.1162/REST_a_00093

Benek-Rivera, J., \& Mathews, V. (2004, February). Active Learning with Jeopardy: Students as the Questions. Journal of Management Education, 28, 104-118. https://doi.org/10.1177/1052562903252637

Bloom, B. (1956). Taxonomy of Educational Objectives, Handbook I: The Cognitive Domain. New York, NY: David McKay.

Brecht, H., \& Ogilby, S. (2008). Enabling a Comprehensive Teach Strategy: Video Games. Journal of Information Techonology Education: Innovations in Practice, 7(1), 71-86.

Buchko, A. (1992, February). Effects of Employee Ownership on Employee Attitudes. Work and Occupations, 19, 59-78. https://doi.org/10.1177/0730888492019001004

Camp, D. (2000). It Takes Two: Teaching with Twin Texts of Fact and Fiction. Reading Teacher, 53(5), 400-409.

Celsi, R., \& Wolfinbarger, M. (2002). Discontinuous Classroom Innovation: Waves of Change for Marketing Education. Journal of Marketing Education, 24, 64-72. https://doi.org/10.1177/0273475302241008

Chaplin, S. (2009). Assessment of the Impact of Case Studies on Student Learning Gains in an Introductory Biology Course. Journal of College Science Teaching, 39, 72-79.

Conant, J., Smart, D., \& Kelley, C. (1988). Master Teaching: Pursuing Excellence in Marketing Education. Journal of Marketing Education, 10(Fall), 3-13. https://doi.org/10.1177/027347538801000302

Crouch, C., \& Mazur, E. (2001). Peer Instruction: Ten Years of Experience and Results. American Journal of Psychics, 69(9), 970. https://doi.org/10.1119/1.1374249

Daly, S. (2001). Student-operated Internet Businesses: True Experiential Learning in Entrepreneurship and Retail Management. Journal of Marketing Education, 23, 204-215. https://doi.org/10.1177/0273475301233006

DeLay, R. (1996, August-September). Forming Knowledge: Constructivist Learning and Experiential Education. Journal of Experiential Education, 19, 76-81. https://doi.org/10.1177/105382599601900204

Drea, J., Singh, M., \& Engelland, B. (1997). Using Experiential Learning in a Principles of Marketing Course: An Emperical Analysis of Student Marketing Audits. Marketing Education Review, 7(2), 53-59. https://doi.org/10.1080/10528008.1997.11488591

Duray, R., \& Milligan, G. (1999, August). Improving Customer Satisfaction through Mass Customization. Quality Progress, 32, 60-66.

Educase. (2012). Seven Things You Should Know About Flipped Classrooms. Retrieved from http://www.educause.edu/library/resources/7-things-you-should-know-about-flipped-classrooms.

Ford, J., Ford, L., \& D'Amelio, A. (2008). Resistance to Change: The Rest of the Story. Academy of Management Review, 33(2), 362-377. https://doi.org/10.5465/AMR.2008.31193235 
Freeman, S., O’Connor, E., Parks, J., Cunningham, M, Hurley, D., Dirks, C., \& Wenderoth, M. (2007). Prescribed Active Learning Increases Performance in Introductory Biology. CBE Life Science Education, 6, 132-139. https://doi.org/10.1187/cbe.06-09-0194

Gaidis, W., \& Andrews, J. (1990). Management of Experiential Learning Projects in Marketing Coursework. Journal of Marketing Education, 12(2), 49-60. https://doi.org/10.1177/027347539001200207

Garrison, D., \& Kanuka, H. (2004). Blended Learning: Uncovering its Transformative Potential in Higher Education. Internet and Higher Education, 7, 95-106. https://doi.org/10.1016/j.iheduc.2004.02.001

Garver, M., \& Roberts, B. (2013). Flipping \& Clicking Your Way to Higher-Order Learning. Marketing Education Review, 23(1). https://doi.org/10.2753/MER1052-8008230103

Glenn, D. (2011). The Default Major: Skating Through B-School. The New York Times. Retrieved from http://www.nytimes.com/2011/04/17/education/edlife/edl-17business-t.html

Green, T. (2015). Flipped Classrooms: An Agenda for Innovative Marketing Education in The Digital Era. Marketing Education Review, 25(3), 179-191. https://doi.org/10.1080/10528008.2015.1044851

Haas, R., \& Wotruba, T. (1990). The Project Approach to Teaching the Capstone Marketing Course. Journal of Marketing Education, 12(2), 37-48. https://doi.org/10.1177/027347539001200206

Hart Research Associates. (2013). It Takes More Than a Major: Employer Priorities for College Learning and Student Success. Liberal Education, 99(2).

Hedgcock, W., \& Rouwenhorst, R. (2014). Clicking Their Way to Success: Using Student Response Systems as a Tool for Feedback. Journal for Advancement of Marketing Education, 22(2), 16-25.

Herreid, C., \& Schiller, N. (2013). Case Studies and the Flipped Classroom. Journal of College Science Teaching, 42, $62-66$.

Hughes, H. (2012, March). Customer Reactions to Service Separation. Journal of Marketing, 74, 1-22.

King, A. (1993). From Sage on the Stage to Guide on the Side. College Teaching, 41, 30-35. https://doi.org/10.1080/87567555.1993.9926781

Knight, J., \& Wood, W. (2005). Teaching More by Lecturing Less. Cell Biology Education, 4, 298-310. https://doi.org/10.1187/05-06-0082

Kolb, D. (1984). Experiential Learning: Experience as a Source of Learning and Development. Englewood Cliffs, NJ: Prentice Hall.

Kolb, D., Boyatzis, R., \& Mainemelis, C. (2001). Experiential Learning Theory: Previous Research and New Directions. In R. Sternberg \& L Zhang (Eds.), Perspectives on Thinking, Learning, and Cognitive Styles (pp. 227-247). Mahwah, NJ: Lawrence Erlbaum.

Kunkel, G., \& Shafer, W. (1997). Effects of Student Team Learning in Undergraduate Auditing Courses, Journal of Education for Business, 72(March-April), 197-200. https://doi.org/10.1080/08832323.1997.10116853

Lang, M., Platt, G., \& Treglia, M. (2000). Inverting the Classroom: A Gateway to Creating an Inclusive Learning Environment. Journal of Economic Education, 31(2), 30-43.

LEAP Initiative. (2013). High-Impact Practices. Association of American Colleges \& Universities.

Margerison, C. (1988). Action Learning and Excellence in Management Development. Journal of Management Development, 7(5), 43-53. https://doi.org/10.1108/eb051690

McCormick, D. (1993). Critical Thinking, Experiential Learning, and Internships. Journal of Management Education, 17(2), 260-262. https://doi.org/10.1177/105256299301700211

Meyers, C., \& Jones, T. (1993). Promoting Active Learning: Strategies for the College Classroom. San Francisco: Jossey-Bass.

Nonis, S., \& Hudson, G. (2006). Academic Performance of College Students: Influence of Time Spent Studying and Working. Journal of Education for Business, 81, 151-159. https://doi.org/10.3200/JOEB.81.3.151-159

NSSE. (2014). Bringing the Institution into Focus: Annual Results for 2014. National Survey of Student Engagement.

Oreg, S. (2003). Resistance to Change: Developing an Individual Differences Measure. Journal of Applied Psychology, 88(4), 680-693. https://doi.org/10.1037/0021-9010.88.4.680 
Parker, J., Maor, D., \& Herrington, J. (2013). Authentic Online Learning: Aligning Learner Needs, Pedagogy an Technology. Issues in Educational Research, 23(2), 227-241.

Pascarella, E., Blaich, C., Martin, G., \& Hanson, J. (2011). How Robust are the Findings of Academically Adrift. Change, 43(3), 20-24. https://doi.org/10.1080/00091383.2011.568898

Pfeffer, J., \& Fong, C. (2002). The End of Business Schools? Less Success than Meets the Eye. Academy of Management Learning and Education, 1, 78-95. https://doi.org/10.5465/AMLE.2002.7373679

Prashar, A. (2015). Assessing the Flipped Classroom in Operations Management: A Pilot Study. Journal of Education for Business, 90(3). https://doi.org/10.1080/08832323.2015.1007904

Prince, M. (2004). Does Active Learning Work? A Review of the Research. Journal of Engineering Education, 93, 223-231. https://doi.org/10.1002/j.2168-9830.2004.tb00809.x

Roach, S., Johnston, M., \& Hair Jr., J. (1993). An Exploratory Examination of Teaching Styles Currently Employed in Marketing Education: Developing a Typology and its Implication for Marketing Students. Journal of Marketing Education, 15(Fall), 32-38. https://doi.org/10.1177/027347539301500305

Roksa, J., \& Arum, R. (2011), The State of Undergraduate Learning. Change: The Magazine of Higher Learning, 43(2), 35-38. https://doi.org/10.1080/00091383.2011.556992

Russell-Bennett, R., Rundle-Thiele, S., \& Kuhn, K. (2010). Engaging Marketing Students: Student Operated Business in a Simulated World. Journal of Marketing Education, 32(3), 253-263. https://doi.org/10.1177/0273475310377758

Scovotti. C. (2016). Experiences with Flipping the Marketing Capstone Course. Marketing Education Review, 26(1), 51-56. https://doi.org/10.1080/10528008.2015.1091675

Slavin, R. (1983). When Does Cooperative Learning Increase Achievement?. Psychological Bulletin, 94, 429-445. https://doi.org/10.1037/0033-2909.94.3.429

Snowball, J. (2014). Using Interactive Content and Online Activities to Accommodate Diversity in a Large First Year Class. Higher Education, (January).

Steed, A. (2012). The Flipped Classroom. Teaching Business \& Economics, 16(3), 9-11.

Waddell, D., \& Sohal, A. (1998). Resistance: A Constructive Tool for Change Management. Management Decision, 36(8), 543-548. https://doi.org/10.1108/00251749810232628

Wertsch, J. (1984). The Zone of Proximal Development: Some Conceptual Issues. New Directions for Child and Adolescent Development, 23, 7-18. https://doi.org/10.1002/cd.23219842303

Whitener, E. (2001). Do 'High Commitment' Human Resource Practices Affect Employee Commitment? A Cross-Level Analysis Using Hierarchical Linear Models. Journal of Management, 27(5), 515-535.

Wood, C. (2003). The Effects of Creating Psychological Ownership among Students in Group Projects. Journal of Marketing Education, 25(3), 241-249. https://doi.org/10.1177/0273475303257553

Zappe, S., Leicht, R., Messner, J., Litzinger, T., \& Lee, H. (2009). Flipping the Classroom to Explore Active Learning in a Large Undergraduate Course, Paper presented at the American Society for Engineering Education Annual Conference, Portland, Oregon. 